\title{
Adoption Practice of Climate Change Adaptation Options among Nepalese Rice Farmers: Role of Information and Communication Technologies (ICTs)
}

\author{
Niranjan Devkota ${ }^{1 *}$, Ram Kumar Phuyal ${ }^{2 \#}$ \\ ${ }^{1}$ Tribhuvan University, Kathmandu, Nepal \\ ${ }^{2}$ Center for Economic Development and Administration, Tribhuvan University, Kathmandu, Nepal \\ Email: \#phuyal_ram5@yahoo.com
}

How to cite this paper: Devkota, N. and Phuyal, R.K. (2018) Adoption Practice of Climate Change Adaptation Options among Nepalese Rice Farmers: Role of Information and Communication Technologies (ICTs). American Journal of Climate Change, 7, 135-152.

https://doi.org/10.4236/ajcc.2018.72010

Received: January 10, 2018

Accepted: May 6, 2018

Published: May 9, 2018

Copyright $\odot 2018$ by authors and Scientific Research Publishing Inc. This work is licensed under the Creative Commons Attribution International License (CC BY 4.0).

http://creativecommons.org/licenses/by/4.0/

cC) (7) Open Access

\begin{abstract}
This study attempts to understand the role of ICTs on adoption of climate change adaption options among the Nepalese rice farmers, using data from 773 households from seven districts-3 from Terai region and 4 from hilly region. Individual Farmer's Awareness Index was developed to categorize the respondent knowledge of climate change adaptation and Ordered Logit Model was used to examine the factors influencing their adaptation options in present of ICTs. The result revealed that $65 \%$ farmers perceived knowledge about temperature, rainfall and other relative information from various ICT devices that they pose. Farmers received such information mostly from Radio (71\%), TV (69\%) and mobile phone (62.5\%) and argued these three devices are the most prominent, easy access and practical devices to receive such information. $86 \%$ farmers used such devices on the daily basis and $90 \%$ and more users opined that the information provided from such devices is in their own language and fully understandable. From ICT devices they pose, $71 \%$ of the farmers are receiving climate change information and $61 \%$ received agro-related information and the majority of them argued that such available information is very much informative and supportive of their resilience to climate change and use of available adaptation options. From the Farmers Awareness Index, this study found $19.8 \%$ farmers are high aware, $65.1 \%$ medium aware and $15.1 \%$ were less aware of the changing climate and its anomalies. Similarly, result from Ordered Logit Model shows that age $\left(0.45^{* * *}\right)$, gender $\left(0.48^{* *}\right)$, market center $\left(0.32^{*}\right)$, bank access $\left(0.54^{* * *}\right)$, availability of subsidy $\left(1.0^{* * *}\right)$, agro-extension services $\left(0.71^{\star *}\right)$, access to TV $\left(0.67^{\star * *}\right)$ and membership to a social network $\left(3.20^{* *}\right)$ played a significant role in increasing
\end{abstract}

*https://orcid.org/0000-0001-9989-0397. 
farmers' awareness of climate change which in turn lead to increased adoption of adaptation options available to the farmers. The findings suggest the need for further improvement on ICT devices and publicity of such ICT devices and proper investment to boost rice farmers' adaptation to climate change, which will in turn help to improve their livelihoods and well-being.

\section{Keywords}

Climate Change Adaptation, Rural Rice Farmers, ICTs, Ordered Logit, Nepal

\section{Background}

With the recognition of climate change as a serious concern since the 1980s, research on climate change and its adaptive measures in the agricultural sector has been a core topic for the agro-scientists, economists and policy makers [1]. The concept of climate change adaptation-an adjustment to decrease the vulnerability of agriculture to climate change, has been popularized and is now widely accepted from grass root level to the policy level [2] [3]. Several studies have already been conducted to gauge climate change adaptation and its impact, consequences and remedies in sectors including agriculture and rice production from macro to micro level, as well as world to regional level. However, further development, exploration and explanation of the issue are still going on.

Rice is one of the major crops to feed the world's growing population, and over a longer time, it has fed more people than any other crop [4] [5]. Most of the rice is grown and consumed in Asia, from Pakistan in the west to Japan in the east [5]. Rice is the primary staple food and the most important crop in South Asia. It ranks first in Nepal in terms of area, production and its contribution to livelihoods [6]. Rice contributes significantly to food security. Its consumption in Nepal is $79.9 \mathrm{~kg}$ of milled rice per person per year [3] [7].

While rice is very important to people's livelihoods, its production is already under pressure. From the demand side, it is population growth, while on the supply side, further exposure to natural pressure through climate change (CC) is having marked impacts [8]. In addition, CC brings several new challenges. Many studies, including the Intergovernmental Panel on Climate Change (IPCC) observed that the net cereal production in South Asian countries is projected to decline at least between $4 \%$ and $10 \%$ by the end of this century under the most conservative climate change scenario [2]. A similar report shows that rice production in Asia could decline by $3.8 \%$ by the end of the 21 st century and in Nepal, production of rice might drop by $4.2 \%$ by 2060 [9]. To cope with such possible negative impacts, adaptation can be one of the better options [3]. Given this background, it is necessary to examine the status of adaptation options in economic and social systems so as to help inform future actions.

Numerous studies have been undertaken in South Asia on the effects of CC on rice production and adaptation [1] [3] [7] [8] [9] [10]. These studies reveal that 
farmers have been adopting several adaptation options to cope with changes in the climate. It is noted that efficient adaptation options help to maximize net benefit [3] [7] [11]. In this regard, ICTs can assist farmers to understand better adaptation techniques and enhance their knowledge regarding new adaptation options. ICTs tools are increasingly becoming popular among farming communities [12], and they are playing an important role in disseminating the knowledge on adaptation and fighting against climate change [13]. Though ICTs are or can be key enablers of adaptation [14], there are very limited empirical studies on their role in the adoption of CC adaptation options on South Asian rice production. There is a need to understand their functioning in this particular agricultural system. As observed by [15], before any attempt is made to replicate ICTs, it is required to have a clear picture about how the ICTs can play beneficial role in terms of improvement in income level and the livelihoods of farmers.

[16] [17] and [18] recognized the arrival of ICTs as well timed, and a solution to improve agricultural production in developing countries. Recently, the use of ICTs in the forms of mobile phones and the internet has been increasing. In Nepal, the number of mobile subscribers reached 27.07 million by 2016, which is 102.18 percent of the total population. Similarly, internet penetration has reached 44.89 percent of the total population [19]. But, questions then arise like whether ICTs are available to the rice farmers of South Asia? How do South Asian rice farmers use ICTs in CC adaptation? Are such ICTs useful and cost efficient? Therefore, this paper aims to investigate in a real scenario and the feasibility of ICT applications on CC adaptation by the rural rice farmers in Nepal.

The remaining part of the paper is organized in four sections. In the next section, literature review is discussed which is followed by materials and methods used, then the results of the study, discussion of key issues and finally concluding remarks.

\section{Literature Review}

ICT has revolutionized the whole world and its growth over the last decades has been phenomenal [13] [20]. ICT includes knowledge centers, community radio, mobile phones and interaction media [21]. The use of ICTs and their applications is getting more attention across the world, with the recognition that they are efficient tools for promoting economic growth and sustainable development [21] [22]. [12] argues ICT plays an important role in improving the availability of market information and agricultural development particularly in developing countries. Many environmental studies include ICT in their study to detangle the problem of environment and changing climate [21].

In recent years, many environmental studies have tried to establish a relationship between ICTs and agricultural production including rice [13] [23] [24] [25]. Various studies have produced empirical evidence suggesting that substantial productivity gains have been experienced from ICT usage [22]. 
[26] examines the role of ICTs in climate change awareness in two districts of rural Zimbabwe; the study found that ICTs played an important role in conveying agricultural as well as climate change information. Similarly, [27] used content analysis and semiotics method to study what is the ICT profile of a modern firm and how the family and the environment do affect the configuration of the profile. [28] studied the application of short-term rainfall forecasts in irrigation management as a soft adaptation to Climate Change in rice farming. Using the SWAP model, they found that the decision to irrigate rice on short-term weather forecasts could reduce average water application by $27 \%$; 5 -day perfect rainfall forecasts could lead to a saving of $32 \%$ of irrigation water compared to current water usage.

According to [23] adaptation remains one of the least explored areas for analysis of ICTs potential in the global south. [13] also notes that developing countries have not yet effectively integrated ICTs into CC adaptation planning. Unfortunately as [29] argues most of the vulnerable and at most risk, live in the developing world.

ICTs can play an important role in uplifting the livelihoods of the rural poor smallholder farmers [15] [22]. Linking knowledge to innovation is crucial in addressing information and knowledge gaps in the agriculture sector [20]. The role of ICTs is applicable to adaptation in all sectors. As [15] stated that up to date information through ICT allows farmers to survive and even benefit from the changes and challenges. In this context, ICTs can play an important role in climate change monitoring and adaptation. However, as [30] mentioned that the application of ICTs in CC mitigation and adaptation domain is still missing to a large extent.

[31] states that ICT has been deployed in agriculture in several countries, notably India, Pakistan and Uganda but the greatest success seems to have been in India. In his study [32] mentioned that while people are enjoying the opportunity brought about by ICTs in the era of Globalization, farmers in Bangladesh are still enjoying traditional methods. In such developing countries where traditional farming method are the norm, continuous efforts are required to motivate farmers to adopt ICT for application in their farming and business operations. Already, some mobile phone applications (apps) have been developed and applied in Nepal; they provide information to the farmers regarding prices and other information. However, these apps have limited information and cover only negligible farmers.

ICTs have been shown to increase incomes in the agriculture sector. With the growing mobile, wireless and internet industries, ICT have been found to have a positive effect on livelihoods, even among poor smallholder farmers [15]. Investment in ICTs has been found to be positively correlated with country's GDP [33]. [20] in his study observed that the increasing use of mobile phone for information exchange, such as disease surveillance and pest tracking, is now common practice. In this scenario, an understanding of factors associated with 
ICT adoption and use in agriculture will enable the development of strategies to promote their increased use and effectiveness [24]. On the other side, farmer's perception of the role of ICTs in disseminating agricultural information is important in their adoption and use [34]. In a nutshell, ICT can also play a very important role in bridging the information gap in the agricultural sector.

Given this background, it is necessary to understand the role of ICTs in agricultural production processes, their availability, and how farmers' perceive them. While this is important, it is noteworthy to highlight that there has been limited study on the potential role that ICTs can play in addressing climate change among rice farmers in South Asia. Actually, no study in this regard has been done in the Nepalese context. For some of the studies that have been undertaken in South Asia that tried to explore the application of ICTs in agriculture and climate change, these have many limitations including methodological issues and data problems. Therefore, the present study attempts to cover this gap.

\section{Materials and Methods}

\subsection{The Basic Model}

Since better adaptation options can help to achieve sustainable livelihoods and mitigate the problem of climate change, these should be promoted and popularized through ventilating the proper information to the farmers on time by various measures [10]. However, the decision on whether or not to adapt any adaptation option depends upon the general framework of utility and profit maximization [3] [35] [36]. It is assumed that a rational farmer uses adaptation methods only when the net benefit from using such a method is significantly greater than in the case without it [11]. Thus, this study uses the production and profit maximization approaches to test the hypothesis.

The basic model can be written as:

$$
y_{i}^{*}=x_{i}^{\prime} \beta+u_{i}
$$

In Equation (1) as $y^{*}$ crossess a series of increasing unknown thresholds we move up the ordering of alternatives and $x_{i}^{\prime}$ is the socio economic characteristics, climatic and ICTs characteristics etc. The general form of an ordered model (with $\mathrm{m}$-alternatives) is shown by following equation:

$$
y_{i}=j \text { if } \propto_{j-1}<y_{i}^{*} \leq \propto_{j}
$$

where, $\propto_{0}=-\infty$ and $\propto_{m}=\infty$ then,

$$
\begin{aligned}
\operatorname{Pr}\left[y_{i}=j\right] & =\operatorname{Pr}\left[\propto_{j-1}<y_{i}^{*} \leq \propto_{j}\right] \\
& =\operatorname{Pr}\left[\propto_{j-1}<x_{i}^{\prime} \beta+u_{i} \leq \propto_{j}\right] \\
& =\operatorname{Pr}\left[\propto_{j-1}<x_{i}^{\prime} \beta<u_{i} \leq \propto_{j}-x_{i}^{\prime} \beta\right] \\
& =F\left(\propto_{j}-x_{i}^{\prime} \beta\right)-F\left(\alpha_{j-1}-x_{i}^{\prime} \beta\right),
\end{aligned}
$$

where, $F$ is the cumulative distribution function of $u_{i}$. The regression parameter $\beta$ and the $(m-1)$ threshold parameters $\propto_{1}, \cdots, \propto_{m-1}$ are obtained by maximiz- 
ing the log-likelihood and can be shown as:

$$
\mathcal{L}=\ln L_{N}=\sum_{i=1}^{N} y_{i j} \ln p_{i j} \sum_{j}^{m} y_{i j} \ln p_{i j}
$$

It is important to realize that there are two models that are classified as ordered multinomial models; these are ordered logit model and ordered probit model. For ordered logit model $u$ is logistic distribution with $F(Z)=\mathrm{e}^{z} /\left(1+\mathrm{e}^{z}\right)$. For the ordered probit model $u$ is standard normal distribution and $F(\cdot)$ is the standard normal cumulative distribution function. The sign of $\beta$ is interpreted as determining whether or the latent variable $y^{*}$ increases with the regressor. This study will use the ordered logit model following [37] and [38].

First, this study calculates farmers awareness index. [39] assessed farmers' knowledge about pest management in Srilanka by separating farmers into three groups i.e. low, moderate and high level of knowledge based on knowledge scale. With the three different values that we will be derived from three different groups, the application of the ordered logit model is suitable for this study, as discussed earlier which is the regression model with an ordinal dependent variable. The null hypothesis for this study is that ICTs do not play significant role in the adoption of climate change adaptation options among rural rice producing farmers in Nepal.

\subsection{Calculation of Farmers Awareness Index}

Several studies have attempted to formulate the farmers awareness index. Such index helps to measure awareness level of farmers regarding climate change adaptation with the help of ICTs. [39] assessed farmers' knowledge about pest management in Srilanka by separating farmers into three groups i.e. low, moderate and high level of knowledge based on knowledge scale. On another study, [40] measured personal perceived risk to climate change by constructing an index by aggregating 17 items. [41] applied 9 items to compute an awareness index. Similarly, [42] developed a climate change awareness index using 11 items.

Based on the studies, we develop individual farmer's Awareness Index (FAI) measured by dummy-based index as [42]. This dummy based index includes 1 for each argued answer of an individual and 0 for others. As there are $12 \mathrm{FAI}$ items, the theoretical range of the dummy-based index is 0 to 12 , with larger values indicating a higher FAI. Following [39] this study also used mean and standard deviation of measurement to categorize the respondents' knowledge into three groups. The farmers' awareness index can be calculated by using the formula:

$$
Y(C C A)= \begin{cases}Y=1, & \text { If Scale Score }<\bar{X}-S D \\ Y=2, & \text { If } \bar{X}-S D<\text { Scale Score }<\bar{X}+S D \\ Y=3, & \text { If Scale Score }>\bar{X}+S D\end{cases}
$$

where,

$$
\bar{X} \text {-Mean of knowledge and awareness of farmers, }
$$




\section{$S D$ - standard deviation.}

As we get the three different values from the three different groups, we applied ordered logit model as discussed earlier. Hence, the dependent variable is the ordered climate change awareness variable $(1=$ low aware; $2=$ medium aware; $2=$ high aware) whereas the independent variables comprised ICT access variables and other socio-economic characteristics. Since this study seeks to analyze the contribution of ICTs to climate change adaptation in rice production amongst rural farmers with a particular focus on the importance of information, communication and knowledge. Thus the variable included were mainly determined by and related to livelihood assets that influence access to and uses of information, communication and knowledge as given in Table 1 .

Table 1. Description of explanatory variables used in the model.

\begin{tabular}{|c|c|c|c|c|}
\hline Explanatory Variables & Mean & SD & Description & $\begin{array}{c}\text { Expected } \\
\text { Sign }\end{array}$ \\
\hline Age & 47.74 & 13.14 & Continuous & $( \pm)$ \\
\hline Marital status & 0.93 & 0.26 & Dummy takes the value 1 if married and 0 otherwise & $( \pm)$ \\
\hline Gender & 0.71 & 0.45 & Dummy takes the value 1 if gender is male and 0 otherwise & $( \pm)$ \\
\hline Household head & 0.80 & 0.40 & Dummy takes the value 1 if $\mathrm{HH}$ head is male and 0 otherwise & $(+)$ \\
\hline Level of education & 0.08 & 0.27 & Dummy takes the value 1 if education is higher than secondary level and 0 otherwise & $(+)$ \\
\hline Total farmland & 0.68 & 0.78 & Continuous & $(+)$ \\
\hline Farm Experience & 29.01 & 13.28 & Continuous & $(+)$ \\
\hline Membership of Organization & 0.21 & 0.41 & Dummy takes the value 1 if have membership of organization and 0 otherwise & $(+)$ \\
\hline Training & 0.05 & 0.22 & Dummy takes the value 1 if received training and 0 otherwise & $(+)$ \\
\hline Market Center & 0.22 & 0.41 & Dummy takes the value 1 if have access to market center and 0 otherwise & $(+)$ \\
\hline Bank Access & 0.27 & 0.44 & Dummy takes the value 1 if have access to bank and 0 otherwise & $(+)$ \\
\hline Availability of Subsidy & 0.08 & 0.26 & Dummy takes the value 1 if have access to subsidy and 0 otherwise & $(+)$ \\
\hline Climate Change Knowledge & 0.75 & 0.43 & Dummy takes the value 1 if have CC knowledge and 0 otherwise & $(+)$ \\
\hline Agriculture Extension Service & 0.07 & 0.25 & Dummy takes the value 1 if have access to extension services and 0 otherwise & $(+)$ \\
\hline Access to TV & 0.43 & 0.50 & Dummy takes the value 1 if have access to TV and 0 otherwise & $(+)$ \\
\hline Access to Radio & 0.44 & 0.50 & Dummy takes the value 1 if have access to Radio and 0 otherwise & $(+)$ \\
\hline Access to Mobile & 0.39 & 0.49 & Dummy takes the value 1 if have access to mobile and 0 otherwise & $(+)$ \\
\hline Access to Newspaper & 0.03 & 0.18 & Dummy takes the value 1 if have access to newspaper and 0 otherwise & $(+)$ \\
\hline Access to Internet & 0.02 & 0.13 & Dummy takes the value 1 if have access to internet service and 0 otherwise & $(+)$ \\
\hline Access to Agro-magazine & 0.01 & 0.08 & Dummy takes the value 1 if have access to agro-magazine and 0 otherwise & $(+)$ \\
\hline Access to poster & 0.01 & 0.10 & Dummy takes the value 1 if have access to poster and 0 otherwise & $(+)$ \\
\hline Access to social network & 0.00 & 0.06 & Dummy takes the value 1 if have access to social network and 0 otherwise & $(+)$ \\
\hline
\end{tabular}

Source: Researcher's calculation/Assumption. 


\subsection{Study Area and Data}

This study was done in 7 districts -3 from Terai region (i.e. Bara, Dang and Kailali) and 4 from Hilly region (i.e. Ilam, Sindhuli, Syangja and Surkhet) of Nepal and excludes the Mountain belt ${ }^{1}$ [3] [7]. Three study districts come from Terai Belt and four from Hilly Belt. The reason behind choosing seven districts is that it was deemed necessary to have one district from each state. This study applied multi-stage sampling technique for the selection of study sites and farm households. In first stage the seven highly rice production districts were randomly selected whereas 14 Village Development Committees (VDCs), two from each district, were selected on the basis of rice pocket area based on telephone inquiry made to each district agriculture office in the second stage. Similarly, in third stage, 28 rice pocket wards, two wards from each VDC, were selected based on the information provided by VDC secretary and Social Mobilizer ${ }^{2}$. The survey was conducted between December 2016 and January 2017 by trained enumerators using a fully structure questionnaire. For the data collection, total 773 farmers were interviewed irrespective of gender, farm size or tenancy status through a farm household survey [3] [7] [10]. Interviews were conducted for the crop year 2016 since main season rice cultivation in Nepal falls on June/July to October/November of each year.

\section{Result and Discussion}

\subsection{Knowledge about ICT Devices}

Information is considered as most crucial factor to acquire knowledge and ICT is its pillar [14] [43] [44]. The availability of more information enhances the adaptive capacity of farmers [45]. Sound and timely information provides a concrete pathway for successful adaptation by the rice farmers. Farmers' having information from ICT devices indicates that they have knowledge about such devices [46]. It is observed that $65 \%$ of farmers in study area perceived knowledge about temperature, rainfall and other related information from the various ICT devices. Farmers received information from various ICT devices as follows, $71 \%$ from radio, $69 \%$ from TV and $62.5 \%$ from mobile phone as depicted in Table 2. However, most of them argued that Radio (44\%), TV (43\%) and mobile phone (39\%) are the most prominent, pertaining and popular ICT devices to get sources of information. Other ICT sources like internet, agro-magazine, poster and social network were rarely used by the farmers.

One of the important reasons for this, could be that the farmers are situated in rural area where both access and awareness about such technology is comparatively less when compared to urban people. Farmers also mentioned that the conveyed information is understandable as it is available in simplest form and in

\footnotetext{
${ }^{1}$ Since rice cultivation practice on mountain belt is very rare and typically different from the study area. Similarly, the rice cultivation period, cultivation techniques and adoption of adaptation options differ from the remaining two belts.

${ }^{2}$ In every VDC there is one social mobilizer whose work is to facilitate VDC secretary.
} 
Table 2. Knowledge and Sources of ICTs among various study regions (multiple responses).

\begin{tabular}{|c|c|c|c|c|}
\hline \multicolumn{2}{|c|}{ Sources of ICTs } & $\begin{array}{c}\text { Total } \\
(\mathrm{n}=773)\end{array}$ & $\begin{array}{l}\text { Hilly Region } \\
\qquad(\mathrm{n}=438)\end{array}$ & $\begin{array}{l}\text { Terai Region } \\
\quad(\mathrm{n}=335)\end{array}$ \\
\hline \multicolumn{2}{|c|}{ Information on ICT among farmers } & $480(65.48 \%)$ & $278(63.47 \%)$ & $202(60.30 \%)$ \\
\hline \multirow{10}{*}{$\begin{array}{l}\text { Sources of } \\
\text { Information } \\
\text { (Multiple } \\
\text { Response) }\end{array}$} & Agriculture Extension Service & $52(7.09 \%)$ & $38(8.68 \%)$ & $14(4.18 \%)$ \\
\hline & TV & $330(45.02 \%)$ & $204(46.58 \%)$ & $126(37.61 \%)$ \\
\hline & Radio & $341(46.52 \%)$ & $217(49.54 \%)$ & $124(37.01 \%)$ \\
\hline & Newspaper & $34(4.64 \%)$ & $27(6.16 \%)$ & $7(2.09 \%)$ \\
\hline & Mobile & $300(40.93 \%)$ & $163(37.21 \%)$ & $137(40.90 \%)$ \\
\hline & Internet & $10(1.36 \%)$ & $6(1.37 \%)$ & $4(1.19 \%)$ \\
\hline & Agro-magazine & $7(0.95 \%)$ & $6(1.37 \%)$ & $1(0.30 \%)$ \\
\hline & Poster & $11(1.50 \%)$ & $8(1.83 \%)$ & $3(0.90 \%)$ \\
\hline & Social Network & $7(0.95 \%)$ & $4(0.91 \%)$ & $3(0.90 \%)$ \\
\hline & Other & $5(0.68 \%)$ & $5(1.14 \%)$ & $0(0.00 \%)$ \\
\hline
\end{tabular}

Source: Researcher's calculation based of field data, 2017; number in parenthesis represent percentage.

the National language (i.e. Nepali). 93\% of the respondents argued that they received such information in their own language and $91 \%$ of them opined that they understood such information completely. However, some of the women who belong to special tribe of Terai region seemed to have problem in such understanding as they do not understand national language properly.

\subsection{Access and Use of ICT Devices}

Having ICT access allows farmers to get information in a timely and convenient way, which helps them to react with suitable actions to the problem they encounter. Access to several ICTs is generally not widely available in the country. Farmers in the different rice production system such as irrigation and rainfed are aware of the issue regarding climate change and will often ascribe change in farm productivity to changes in temperature and rainfall patterns. However, the nature of climate variation depends on how people perceive climate change and variability.

The impact of climate change depends on the vulnerability of rice production to changes in temperature and rainfall, and the magnitude of impacts varies between irrigated to rainfed systems. The impact can be negative if change in the climate results in high temperature, low rainfall, occurrence of floods, low crop yields and so on. These impacts determine what adaptation options (short-term or long-term adaptations) farmers should take to protect themselves from the effect of climate change and variability. Adaptation options for rice production include selecting short duration crop varieties, planting drought resident crops, crop diversification, use of chemical fertilizer, irrigation, changing nursery date, changing the plant date and so on. 
Though there are bulks of adaptation options available to cope with climate induced vulnerability in the country, farmers do not behave irrationally while choosing adaptation options available in the market. It depends upon the knowledge and information they do have regarding adaptation options. We assume that the more information they have regarding climate change and its impact, the more would be their adaptive capacity. Information and communication helps farmers to know the timing. Among the devices mobile phone (84\%) was the most accessed ICTs among the rural farmers, followed by Radio and TV (both 53\%). Rest of the ICT access is insignificant compared to these three ICTs. Farmers preferred radio (47\%), TV (42\%) and mobile phone (32\%) in acquiring information and knowledge related to rice farming. Only $10 \%$ farmers depended on agriculture extension services for that purpose. Rice farmers' capacity to afford mentioned ICT devices was found to be higher i.e. $70 \%$ in study area. Similarly, $67 \%$ of the respondents highlighted that they afforded to repair their ICT devices in case of breakdown.

The actual use of ICT devices is another important aspect among farmers in Nepal. This study found that $86 \%$ of the respondents could use their ICT device with easiness. This was identified more in eastern, central and western part of the country and less in far-western part. Similarly, 90\% respondent mentioned that they used such device on a daily basis. It is noteworthy to point out that some farmers are less educated and less techno-friendly, which can present challenges on the adoption of the devices. Thus, all farmers who can afford the ICTs may not be able to use them appropriately, which implies that in some cases, the devices might not be very useful to the farmers when they fail to fully utilise the capabilities of the devices to get the much needed information even though they might have access to the devices.

\subsection{Agriculture and Climate Related Information Transmission through ICT Devices}

Farmers have to make several decisions during their farming activities. Two most important things for farmers to cope with the changing climate are: whether they receive climate change and agricultural information; and if they received it, to what extent and its relevance to their situation. This study shows two third of the respondents were receiving information related to climate change and agriculture. They received information on heat, cold, extreme events, drought and other agricultural information, which they regarded as very helpful for their awareness and better farming practices. $60 \%$ of that farmers stated that such availed information through ICTs, is very much informative and necessary for enabling their resilience and adaptation to climate change.

\subsection{Result of Farmers Awareness Index for Different Districts}

As highlighted earlier, a farmers' awareness index based on 12 questions was prepared, and the results are presented in Table 3. Based on the calculation, this 
Table 3. Farmers knowledge about climate change adaptation strategies.

\begin{tabular}{|c|c|c|c|c|c|c|c|c|}
\hline & Ilam & Bara & Sindhuli & Syangja & Dang & Surkhet & Kailali & Total \\
\hline Climate change can reduce soil fertility (Yes) & $\begin{array}{c}94 \\
(84 \%)\end{array}$ & $\begin{array}{c}103 \\
(93 \%)\end{array}$ & $\begin{array}{c}93 \\
(88 \%)\end{array}$ & $\begin{array}{c}100 \\
(92 \%)\end{array}$ & $\begin{array}{c}100 \\
(89 \%)\end{array}$ & $\begin{array}{c}99 \\
(89 \%)\end{array}$ & $\begin{array}{c}105 \\
(94 \%)\end{array}$ & $\begin{array}{c}628 \\
(90 \%)\end{array}$ \\
\hline $\begin{array}{c}\text { Climate change can negatively affect rice } \\
\text { production (Yes) }\end{array}$ & $\begin{array}{c}97 \\
(87 \%)\end{array}$ & $\begin{array}{c}103 \\
(93 \%)\end{array}$ & $\begin{array}{c}94 \\
(89 \%)\end{array}$ & $\begin{array}{c}104 \\
(95 \%)\end{array}$ & $\begin{array}{c}104 \\
(93 \%)\end{array}$ & $\begin{array}{c}104 \\
(94 \%)\end{array}$ & $\begin{array}{c}112 \\
(100 \%)\end{array}$ & $\begin{array}{c}650 \\
(93 \%)\end{array}$ \\
\hline $\begin{array}{l}\text { Sudden break in rainfall cannot affect rice } \\
\text { production (Yes) }\end{array}$ & $\begin{array}{c}100 \\
(89 \%)\end{array}$ & $\begin{array}{c}101 \\
(91 \%)\end{array}$ & $\begin{array}{c}94 \\
(89 \%)\end{array}$ & $\begin{array}{c}107 \\
(98 \%)\end{array}$ & $\begin{array}{c}105 \\
(94 \%)\end{array}$ & $\begin{array}{c}103 \\
(93 \%)\end{array}$ & $\begin{array}{c}110 \\
(98 \%)\end{array}$ & $\begin{array}{c}652 \\
(93 \%)\end{array}$ \\
\hline $\begin{array}{c}\text { Seeking for early warning information on climate } \\
\text { change is a waste of time because it is not } \\
\text { necessary (Yes) }\end{array}$ & $\begin{array}{c}82 \\
(73 \%)\end{array}$ & $\begin{array}{c}78 \\
(70 \%)\end{array}$ & $\begin{array}{c}77 \\
(73 \%)\end{array}$ & $\begin{array}{c}92 \\
(84 \%)\end{array}$ & $\begin{array}{c}68 \\
(61 \%)\end{array}$ & $\begin{array}{c}58 \\
(52 \%)\end{array}$ & $\begin{array}{c}64 \\
(57 \%)\end{array}$ & $\begin{array}{c}471 \\
(67 \%)\end{array}$ \\
\hline $\begin{array}{l}\text { Climate change increases invasion of pests and } \\
\text { diseases that hampers rice production (Yes) }\end{array}$ & $\begin{array}{c}91 \\
(81 \%)\end{array}$ & $\begin{array}{c}104 \\
(94 \%)\end{array}$ & $\begin{array}{c}90 \\
(85 \%)\end{array}$ & $\begin{array}{c}105 \\
(96 \%)\end{array}$ & $\begin{array}{c}106 \\
(95 \%)\end{array}$ & $\begin{array}{c}94 \\
(85 \%)\end{array}$ & $\begin{array}{c}107 \\
(96 \%)\end{array}$ & $\begin{array}{c}631 \\
(90 \%)\end{array}$ \\
\hline $\begin{array}{l}\text { Shifting planting date is one way of coping with } \\
\text { climate change (Yes) }\end{array}$ & $\begin{array}{c}52 \\
(46 \%)\end{array}$ & $\begin{array}{c}57 \\
(51 \%)\end{array}$ & $\begin{array}{c}45 \\
(42 \%)\end{array}$ & $\begin{array}{c}57 \\
(52 \%)\end{array}$ & $\begin{array}{c}60 \\
(54 \%)\end{array}$ & $\begin{array}{c}40 \\
(36 \%)\end{array}$ & $\begin{array}{c}45 \\
(40 \%)\end{array}$ & $\begin{array}{c}322 \\
(46 \%)\end{array}$ \\
\hline $\begin{array}{c}\text { Avoidance of flood prone areas can reduce rice } \\
\text { losses (Yes) }\end{array}$ & $\begin{array}{c}93 \\
(83 \%)\end{array}$ & $\begin{array}{c}92 \\
(83 \%)\end{array}$ & $\begin{array}{c}79 \\
(75 \%)\end{array}$ & $\begin{array}{c}87 \\
(80 \%)\end{array}$ & $\begin{array}{c}86 \\
(77 \%)\end{array}$ & $\begin{array}{c}84 \\
(76 \%)\end{array}$ & $\begin{array}{c}88 \\
(79 \%)\end{array}$ & $\begin{array}{c}551 \\
(79 \%)\end{array}$ \\
\hline $\begin{array}{c}\text { Use of supplementary irrigation is a means of } \\
\text { coping with water scarcity (Yes) }\end{array}$ & $\begin{array}{c}88 \\
(79 \%)\end{array}$ & $\begin{array}{c}96 \\
(86 \%)\end{array}$ & $\begin{array}{c}78 \\
(74 \%)\end{array}$ & $\begin{array}{c}99 \\
(91 \%)\end{array}$ & $\begin{array}{c}99 \\
(88 \%)\end{array}$ & $\begin{array}{c}94 \\
(85 \%)\end{array}$ & $\begin{array}{c}102 \\
(91 \%)\end{array}$ & $\begin{array}{c}594 \\
(85 \%)\end{array}$ \\
\hline $\begin{array}{l}\text { Planting of improved varieties can reduce negative } \\
\text { impact of climate change on rice production (Yes) }\end{array}$ & $\begin{array}{c}48 \\
(43 \%)\end{array}$ & $\begin{array}{c}76 \\
(68 \%)\end{array}$ & $\begin{array}{c}64 \\
(60 \%)\end{array}$ & $\begin{array}{c}80 \\
(73 \%)\end{array}$ & $\begin{array}{c}96 \\
(86 \%)\end{array}$ & $\begin{array}{c}61 \\
(55 \%)\end{array}$ & $\begin{array}{c}58 \\
(52 \%)\end{array}$ & $\begin{array}{c}438 \\
(62 \%)\end{array}$ \\
\hline $\begin{array}{c}\text { Insuring farm against risk is a way of coping with } \\
\text { climate change (Yes) }\end{array}$ & $\begin{array}{c}53 \\
(47 \%)\end{array}$ & $\begin{array}{c}55 \\
(50 \%)\end{array}$ & $\begin{array}{c}48 \\
(45 \%)\end{array}$ & $\begin{array}{c}66 \\
(61 \%)\end{array}$ & $\begin{array}{c}60 \\
(54 \%)\end{array}$ & $\begin{array}{c}51 \\
(46 \%)\end{array}$ & $\begin{array}{c}56 \\
(50 \%)\end{array}$ & $\begin{array}{c}352 \\
(50 \%)\end{array}$ \\
\hline $\begin{array}{l}\text { Participation in workshops and conferences cannot } \\
\text { really improve one's adaptation skill and know- } \\
\text { ledge (No) }\end{array}$ & $\begin{array}{c}78 \\
(70 \%)\end{array}$ & $\begin{array}{c}73 \\
(66 \%)\end{array}$ & $\begin{array}{c}68 \\
(64 \%)\end{array}$ & $\begin{array}{c}90 \\
(83 \%)\end{array}$ & $\begin{array}{c}61 \\
(54 \%)\end{array}$ & $\begin{array}{c}54 \\
(49 \%)\end{array}$ & $\begin{array}{c}52 \\
(46 \%)\end{array}$ & $\begin{array}{c}432 \\
(62 \%)\end{array}$ \\
\hline $\begin{array}{l}\text { Climate change may cause extreme change in } \\
\text { weather condition which can cause sickness among } \\
\text { farm families (Yes) }\end{array}$ & $\begin{array}{c}93 \\
(83 \%)\end{array}$ & $\begin{array}{c}92 \\
(83 \%)\end{array}$ & $\begin{array}{c}89 \\
(84 \%)\end{array}$ & $\begin{array}{c}92 \\
(84 \%)\end{array}$ & $\begin{array}{c}90 \\
(80 \%)\end{array}$ & $\begin{array}{c}91 \\
(82 \%)\end{array}$ & $\begin{array}{c}96 \\
(86 \%)\end{array}$ & $\begin{array}{c}582 \\
(83 \%)\end{array}$ \\
\hline
\end{tabular}

Source: Researcher's calculation from field data, 2017.

study found out that from a total of 773 respondents, 117 (i.e. 15.1\%) respondents were in low awareness category, 503 (65.1\%) respondents in the medium awareness category, while the rest 153 (19.8\%) respondents were in the high awareness category. Such high awareness is more in Terai region compared to the hilly region. Our findings are similar to the findings from other studies, for instance, $[41]-58.6 \%$ and $[42]-54 \%$.

\subsection{Econometrics Analysis}

The logistic regression model was adopted to check the effect of ICTs on adoption of adaptation options. Normally, cross-sectional data analyses involve two problems i.e. heteroscedasticity in the error term and multicollinearity among explanatory variables [3] [7] [47]. The Collin test was performed to deal with the 
problem of multicollinearity and found VIF score for all models is less than 1.61. Collin test against Breusch-Pagan test for multicollinearity is used in this analysis since Collin test allows direct estimation of multicolliniarity after logit regression while Breusch-Pagan test requires OLS estimation [3] [10]. Similarly, we estimate robust logistic regression in order to prevent model from heteroscedasticity. Some post estimation test like fittest and classification table test was also performed to know the fitness of our model. We test all of our models for significance and accuracy of predictions. The post estimation found that $\chi^{2}$ value is significant and value of Pseudo- $\mathrm{R}^{2}$ ranges from 0.07 to 0.12 and VIF values are in between 1.50 to 1.61 which indicates all models selected for the study are fit and can accurately estimate the impact of ICTs on farmers for the adoption of the climate change adaptation options.

The expected positive influence of farmers awareness index on the role of ICT devices in the adoption of climate change adaptation options can be observed from the regression results. Variables such as age, farm experience, bank access, availability of subsidy, access to TV were found to be significant at $1 \%$ level in Table 4. This indicates that those variables had a strongly influenced the farmers' adaptation since it is strongly associated either positively or negatively with farmers awareness index. Similarly, gender, agriculture extension services, access to road and access to social network are statistically significant at 5\% level of significance. Likewise, market center is significant at $10 \%$ level of significance. This result supports our hypothesis that the high farmers awareness leads to a higher motivation to adopt.

Table 4. Econometric estimation of determinants of farmers awareness.

\begin{tabular}{|c|c|c|c|}
\hline & Overall & Hilly & Terai \\
\hline VARIABLES & Farmers' Awareness & Farmers' Awareness & Farmers' Awareness \\
\hline \multirow[t]{2}{*}{ Age } & $0.0446^{* * *}$ & $0.0476^{* * *}$ & $0.0365^{* *}$ \\
\hline & $(0.0123)$ & $(0.0160)$ & $(0.0176)$ \\
\hline \multirow[t]{2}{*}{ marital_status } & 0.336 & 0.416 & 0.412 \\
\hline & $(0.319)$ & $(0.352)$ & $(0.571)$ \\
\hline \multirow[t]{2}{*}{ Gender } & $0.479^{* *}$ & 0.295 & $0.662^{*}$ \\
\hline & $(0.208)$ & $(0.240)$ & $(0.369)$ \\
\hline \multirow[t]{2}{*}{ hh_head } & 0.0873 & 0.206 & -0.103 \\
\hline & $(0.229)$ & $(0.263)$ & $(0.400)$ \\
\hline \multirow[t]{2}{*}{ level_of_education } & -0.00308 & 0.344 & -0.584 \\
\hline & $(0.288)$ & $(0.331)$ & $(0.500)$ \\
\hline \multirow[t]{2}{*}{ total_farmland } & -0.0306 & 0.235 & -0.0694 \\
\hline & $(0.0804)$ & $(0.369)$ & $(0.113)$ \\
\hline \multirow[t]{2}{*}{ farm_experiance } & $-0.0425^{\star * *}$ & $-0.0400^{* * *}$ & $-0.0486^{* * *}$ \\
\hline & $(0.0117)$ & $(0.0153)$ & $(0.0169)$ \\
\hline
\end{tabular}




\section{Continued}

\begin{tabular}{|c|c|c|c|}
\hline \multirow[t]{2}{*}{ menbership_organization } & 0.0950 & 0.152 & 0.121 \\
\hline & $(0.188)$ & $(0.235)$ & $(0.340)$ \\
\hline \multirow[t]{2}{*}{ Training } & 0.0638 & 0.411 & -0.205 \\
\hline & $(0.306)$ & $(0.511)$ & $(0.535)$ \\
\hline \multirow[t]{2}{*}{ market_center } & 0.323 & 0.239 & 0.242 \\
\hline & $(0.200)$ & $(0.310)$ & $(0.272)$ \\
\hline \multirow[t]{2}{*}{ bank_access } & $0.536^{* * *}$ & $0.787^{\star * *}$ & 0.354 \\
\hline & $(0.180)$ & $(0.255)$ & $(0.276)$ \\
\hline \multirow[t]{2}{*}{ availability_subsidy } & $1.007^{\star * *}$ & 0.0671 & $1.942^{* * *}$ \\
\hline & $(0.347)$ & $(0.521)$ & $(0.467)$ \\
\hline \multirow[t]{2}{*}{ knowledge_cc } & 0.131 & -0.179 & $0.645^{* *}$ \\
\hline & $(0.201)$ & $(0.285)$ & $(0.320)$ \\
\hline \multirow[t]{2}{*}{ agriculture_extension_service } & $0.709^{* *}$ & $0.908^{\star *}$ & 0.541 \\
\hline & $(0.336)$ & $(0.423)$ & $(0.638)$ \\
\hline \multirow[t]{2}{*}{ aceess_tv } & $0.679^{* * *}$ & $0.488^{* *}$ & $0.949 * * *$ \\
\hline & $(0.172)$ & $(0.243)$ & $(0.302)$ \\
\hline \multirow[t]{2}{*}{ access_radio } & $-0.404^{* *}$ & -0.201 & -0.443 \\
\hline & $(0.175)$ & $(0.263)$ & $(0.288)$ \\
\hline \multirow[t]{2}{*}{ access_mobile } & 0.117 & -0.0713 & 0.0814 \\
\hline & $(0.178)$ & $(0.256)$ & $(0.288)$ \\
\hline \multirow[t]{2}{*}{ access_newspaper } & -0.272 & -0.108 & 0.281 \\
\hline & $(0.649)$ & $(0.672)$ & $(1.566)$ \\
\hline \multirow[t]{2}{*}{ access_internet } & -0.766 & $-1.080^{* *}$ & 0.921 \\
\hline & $(0.508)$ & $(0.472)$ & $(1.430)$ \\
\hline \multirow[t]{2}{*}{ access_agromagazine } & 0.227 & 0.101 & 0.0532 \\
\hline & $(0.887)$ & $(0.842)$ & $(2.877)$ \\
\hline \multirow[t]{2}{*}{ access_poster } & -0.826 & 0.202 & -1.744 \\
\hline & $(0.568)$ & $(0.735)$ & $(1.070)$ \\
\hline \multirow[t]{2}{*}{ access_socialnetwork } & $3.207^{* *}$ & $2.684^{* *}$ & 14.11 \\
\hline & $(1.359)$ & $(1.327)$ & $(438.4)$ \\
\hline \multirow[t]{2}{*}{ Constant cut 1} & 0.293 & 0.537 & -0.0837 \\
\hline & $(0.470)$ & $(0.556)$ & $(0.817)$ \\
\hline \multirow[t]{2}{*}{ Constant cut 2} & $3.745^{* * *}$ & $3.908^{* * *}$ & $3.709 * * *$ \\
\hline & $(0.499)$ & $(0.592)$ & $(0.855)$ \\
\hline Observations & 773 & 438 & 335 \\
\hline
\end{tabular}

Robust standard errors in parentheses. ${ }^{* *} \mathrm{p}<0.01,{ }^{* *} \mathrm{p}<0.05,{ }^{*} \mathrm{p}<0.1$. 
Among the significant variable, 9 out of 10 variables show positive sign which indicates that when such variables increase, the farmers awareness is also likely to increase. This can in turn lead to an increased adoption of adaptation options by the farmers. Only one variable i.e. farming experience shows negative sign, which implies that with the several years of farm experience, farmers might adopt less adaptation options in their farming practices. Such farmers might be less flexible and would rather maintain the farming methods they are used to, which might no longer be sustainable in the face of climate change.

\section{Concluding Remarks}

As ICTs are increasingly being used, their progressive and positive role in the development of the agricultural sector especially among Nepalese rice farmers is becoming evident. We observed that the majority of farmers accessed information about climate change from ICT devices; the most common ICTs are TV, Radio and Mobile Phone. More than 90\% of farm households stated that they fully understood the information that is conveyed through various ICT devices, which is helping them to cope with the changing climate. Rice farmers are adapting according to the information they received. The Farmers Awareness index revealed that $58.5 \%$ of the farmers were in the high awareness category, and $33 \%$ were in the medium awareness, while $8.5 \%$ were less aware of climate change. The Ordered Logit Model explained that factors like age, gender, market center, bank access, availability of subsidy, agro-extension services, access to TV, and member of social network played a great role in enhancing the rural rice farmers' awareness of climate change. Greater awareness can enhance the adaptive capacity of farmers. In a nutshell, this study revealed that ICTs are important and are increasingly being used by farmers for various purposes. ICTs were found to provide timely information to the rural farmers which helped them to adapt. This calls on the government together with other stakeholders to further promote access and use of ICTs, especially among rural farmers. Timely and successful dissemination and application of relevant information through ICTs can help to reduce the vulnerability of farming households, which can further promote food security, better livelihoods, and enhance their overall wellbeing.

\section{Acknowledgements}

The authors would like to acknowledge Muhammad Sayeedul Haque, Sushanta Kumar Mahapatra and Ihtsham Ul Haq Padda for their suggestion and contribution on idea development and literature review and Shakespear Mudombi for his comments, suggestions and proofreading in the preliminary draft of the manuscript. The authors declare that there is no competing interest.

\section{References}

[1] Kavikumar, K.S. (2009) Climate Sensitivity of Indian Agriculture: Do Spatial Effect Matter? SANDEE Working Paper No. 45, South Asian Network for Development 
and Environmental Economics (SANDEE), Kathmandu.

[2] IPCC (2007) Impacts, Adaptation and Vulnerability. Contribution of Working Group II to the Fourth Assessment Report of the Intergovernmental Panel on Climate Change. Cambridge University Press, Cambridge.

[3] Devkota, N., Phuyal, R.K. and Shrestha, D.L. (2018) Perception, Determinants and Barriers for the Adoption of Climate Change Adaptation Options among Nepalese Rice Farmers. Agricultural Sciences, 9, 272-298. https://doi.org/10.4236/as.2018.93021

[4] Shimono, H., Kanno, H. and Sawano, S. (2010) Can the Cropping Schedule of Rice Be Adapted to Changing Climate? A Case Study in Cool Areas of Northern Japan. Field crops Research, 118, 126-134. https://doi.org/10.1016/j.fcr.2010.05.001

[5] Maclean, J., Hardy, B. and Hettel, G. (2013) Rice Almanac: Source Book for One of the Most Important Economic Activities on Earth. 4th Edition, International Rice Research Institute, Laguna.

[6] MoAC (2017) Statistical Information on Nepalese Agriculture: 2015/16. Agri-Business Promotion and Statistics Division, Ministry of Agriculture and Cooperatives, Kathmandu.

[7] Devkota, N., Phuyal, R.K. and Shrestha, D.L. (2017) Cost and Benefit Analysis of Adoption of Climate Change Adaptation Options among Rural Rice Farmers in Nepal. Asian Journal of Agriculture and Rural Development, 7, 136-148.

[8] Sarker, A.R.M., Alam, K. and Gow, J. (2013) Assessing the Determinants of Rice Farmers' Adaptation Strategies to Climate Change in Bangladesh. International Journal of Climate Change Strategies and Management, 5, 382-403. https://doi.org/10.1108/IJCCSM-06-2012-0033

[9] Karn, P. (2014) The Impact of Climate Change on Rice Production in Nepal. SANDEE Working Paper No. 85, South Asian Network for Development and Environmental Economics (SANDEE), Kathmandu.

[10] Abid, M., Scheffran, J., Schneider, U.A. and Ashfaq, M. (2015) Farmers' Perceptions of and Adaptation Strategies to Climate Change and Their Determinants: The Case of Punjab Province, Pakistan. Earth System Dynamics, 6, 225. https://doi.org/10.5194/esd-6-225-2015

[11] Mendelsohn, R. (2012) The Economics of Adaptation to Climate Change in Developing Countries. Climate Change Economics, 3, Article ID: 1250006. https://doi.org/10.1142/S2010007812500066

[12] Aldosari, F., Al Shunaifi, M.S., Ullah, M.A., Muddassir, M. and Noor, M.A. (2017) Farmers' Perceptions Regarding the Use of Information and Communication Technology (ICT) in Khyber Pakhtunkhwa-Northern Pakistan. Journal of the Saudi Society of Agricultural Sciences. https://doi.org/10.1016/j.jssas.2017.05.004

[13] Upadhyay, A.P. and Bijalwan, A. (2015) Climate Change Adaptation: Services and Role of Information Communication Technology (ICT) in India. American Journal of Environmental Protection, 4, 70-74. https://doi.org/10.11648/j.ajep.20150401.20

[14] Devkota, N. and Phuyal, R.K. (2017) An Analysis of Nepalese Youth Understanding Level on Climate Change. Asian Journal of Economic Modelling, 5, 342-353. https://doi.org/10.18488/journal.8.2017.53.342.353

[15] Lokeshwori, K. (2016) A Study of the Use of ICT among Rural Farmers. International Journal of Communication Research, 6, 232-238.

[16] George, T., Bagazonzya, H., Ballantyne, P., Belden, C., Birner, R., Del Castello, R. and Treinen, S. (2011) ICT in Agriculture: Connecting Smallholders to Knowledge, 
Networks, and Institutions. World Bank, Washington DC. http://documents.worldbank.org/curated/en/455701468340165132/pdf/646050ESW 0P1180lture0e0Sourcebook12.pdf

[17] Sylvester, G. (2013) Information and Communications Technologies for Sustainable Agriculture. Indicators from Asia and the Pacific. Food and Agriculture Organization of the United Nations, Regional Office for Asia and the Pacific, Bangkok. http://www.fao.org/3/a-i3557e.pdf

[18] Chavula, H.K. (2014) The Role of ICTs in Agricultural Production in Africa. Journal of Development and Agricultural Economics, 6, 279-289. https://doi.org/10.5897/JDAE2013.0517

[19] Nepal Telecom (2016) Nepal Telecom Annual Report, 2015/2016. Kathmandu.

[20] Sylvester, G. (2017) Success Stories on Information and Communication Technologies for Agriculture and Rural Development. Food and Agriculture Organization of the United Nations, Regional Office for Asia and the Pacific, Bangkok. http://www.fao.org/3/a-i4622e.pdf

[21] Shafiq, F., Ahsan, K., AdnanNadeem, M.S., Shaikh, A.B. and Siddiq, M. (2014) Role of ICT in Climate Change Monitoring: A Review Study of ICT Based Climate Change Monitoring Services. Research Journal of Recent Sciences, 3, 123-130.

[22] Sangbuapuan, N. (2012) ICT Policies Influencing Development of Rice Farming in Thailand: A Case Study of the Community Rice Center of the Rice Department. International Journal of Innovation, Management and Technology, 3, 763-768.

[23] Ospina, A.V.H.R. and Heeks, R. (2010) Linking ICTs and Climate Change Adaptation: A Conceptual Framework for eResilience and eAdaptation. Centre for Development Informatics, Institute for Development Policy and Management, University of Manchester. http://www.manchester.ac.uk/cdi

[24] Adegbidi, A., Mensah, R., Vidogbena, F. and Agossou, D. (2012) Determinants of ICT Use by Rice Farmers in Benin: From the Perception of ICT Characteristics to the Adoption of the Technology. Journal of Research in International Business and Management, 2, 273-284.

[25] Rimi, A.T., Francis, A. and Emily, E. (2017) Perceived Effects of Use of Information and Communication Technologies (ICTs) on Rural Farmers' Knowledge in Orlu Agricultural Zone, Imo State. Library Philosophy and Practice (e-journal). http://digitalcommons.unl.edu/libphilprac/1497

[26] ATPS (2013) Contribution of Information and Communication Technologies (ICTs) in Climate Change Awareness in Seke and Murewa Districts of Zimbabwe (Shakespear Mudombi, Mammo Muchie). ATPS Research Paper No. 24. African Technology Policy Studies Network, Nairobi.

[27] Botsiou, M. and Dagdilelis, V. (2013) Aspects of Incorporation of ICT in the Greek Agricultural Enterprises: The Case of a Prefecture. Procedia Technology, 8, 387-396. https://doi.org/10.1016/j.protcy.2013.11.051

[28] Mishra, P.K. and Rai, S.C. (2014) A Cost-Benefit Analysis of Indigenous Soil and Water Conservation Measures in Sikkim Himalaya, India. Mountain Research and Development, 34, 27-35. https://doi.org/10.1659/MRD-JOURNAL-D-12-00013.1

[29] Houghton, J.W. (2009) ICT and the Environment in Developing Countries: An Overview of Opportunities and Developments. Communications \& Strategies, 76, 39-60.

[30] Sala, S. (2010) The Role of Information and Communication Technologies for Community-Based Adaptation to Climate Change. Food and Agriculture Organization of the United Nations, Rome. http://www.fao.org/uploads/media/ap606e_2.pdf 
[31] Sangbuapuan, N. and Guha, S. (2015) Improving Rice Farming in Thailand using Information Kiosks. Information Development, 32, 1372-1386. https://doi.org/10.1177/0266666915598350

[32] Misbahuzzaman, K. (2016) Traditional Farming in the Mountainous Region of Bangladesh and Its Modifications. Journal of Mountain Science, 13, 1489-1502. https://doi.org/10.1007/s11629-015-3541-7

[33] Verider-Chouchance, A. and Karaguezain, C. (2016) Moving towards a Green Productive Agriculture in Africa: The Role of ICTs. African Economic Brief, 7, 1-12. https://www.afdb.org/fileadmin/uploads/afdb/Documents/Publications/AEB_Vol_7 _i_7_-_Moving_towards_a_green_productive_agriculture_in_Africa_The_role_of_I CTs.pdf

[34] Kante, M., Oboko, R. and Chepken, C. (2017) Influence of Perception and Quality of ICT-Based Agricultural Input Information on Use of ICTs by Farmers in Developing Countries: Case of Sikasso in Mali. The Electronic Journal of Information Systems in Developing Countries, 83, 1-21.

[35] Deressa, T., Hassan, R.M., Alemu, T., Yesuf, M. and Ringler, C. (2008) Analyzing the Determinants of Farmers' Choice of Adaptation Methods and Perceptions of Climate Change in the Nile Basin of Ethiopia. IFPRI Discussion Paper No. 798, International Food Policy Research Institute, Washington DC.

[36] Gbetibouo, G.A. (2009) Understanding Farmers' Perceptions and Adaptations to Climate Change and Variability: The Case of the Limpopo Basin, South Africa. IFPRI Discussion Paper 00885, International Food Policy Research Institute, Washington DC.

[37] Mudombi, S. and Muchie, M. (2013) Perceptions of Water Access in the Context of Climate Change by Rural Households in the Seke and Murewa Districts, Zimbabwe. Jàmbá: Journal of Disaster Risk Studies, 5, 1-8. https://doi.org/10.4102/jamba.v5i1.71

[38] Budathoki, N. (2017) Climate Change: Perceptions, Reality and Agricultural Practice: Evidence from Nepal. Sandee Working Paper No. 85, South Asian Network for Development and Environmental Economics (SANDEE), Kathmandu.

[39] Nagenthirarajah, S. and Thiruchelvam, S. (2010) Knowledge of Farmers about Pest Management Practices in Pambaimadu, Vavuniya District: An Ordered Probit Model Approach. Sabaragamuwa University Journal, 8, 79-89.

https://doi.org/10.4038/suslj.v8i1.1852

[40] Osberghaus, D., Dannenberg, A., Mennel, T. and Sturm, B. (2010) The Role of the Government in Adaptation to Climate Change. Environment and Planning C: Government and Policy, 28, 834-850. https://doi.org/10.1068/c09179j

[41] Kutir, C., Baatuuwie, N.B., Keita, S. and Sowe, M. (2015) Farmers Awareness and Response to Climate Change: A Case Study of the North Bank Region, The Gambia. Journal of Economics and Sustainable Development, 6, 32-41.

[42] Mudombi, S., Nhamo, G. and Muchie, M. (2014) Socio-Economic Determinants of Climate Change Awareness among Communal Farmers in Two Districts of Zimbabwe. Africa Insight, 44, 1-15.

[43] Chen, D.H. and Dahlman, C.J. (2004) Knowledge and Development: A Cross-Section Approach. Policy Research Working Paper No. 3366, World Bank, Washington DC. https://doi.org/10.1596/1813-9450-3366

[44] Hadi, S. and Al Rawahi, S. (2014) The Assets of Knowledge Society in Oman: People and ICT. Eurasian Journal of Social Sciences, 2, 1-14.

https://doi.org/10.15604/ejss.2014.02.02.001 
[45] Abdul-Razak, M. and Kruse, S. (2017) The Adaptive Capacity of Smallholder Farmers to Climate Change in the Northern Region of Ghana. Climate Risk Management, 17, 104-122. https://doi.org/10.1016/j.crm.2017.06.001

[46] Abu, T., Francis, A. and Emily, E. (2017) Perceived Effects of Use of Information and Communication Technologies (ICTs) on Rural Farmers' Knowledge in Orlu Agricultural Zone, Imo State. Library Philosophy and Practice (e-journal), 1497. http://digitalcommons.unl.edu/libphilprac/1497

[47] Greene, W.H. (2003) Econometric analysis. Pearson Education, Kannur. 